\title{
Truth Is a Potato: A Journey into Tolstoy's Resurrection
} Ryan Adam

The over-intellectualization of the questions of Truth and Justice only muddy the challenge of living correctly and alienate us from actual, practicable answers, answers which have been here, Leo Tolstoy argues, for millennia. Tolstoy, through the character of Prince Nekhlyudov in Resurrection, opposes simplicity and hard-scrabble peasant wisdom to the labyrinths and mountains of intellectualism and state-sanctioned correctness. This article explores Tolstoy's ideas regarding the nature and substance of Truth, pursing them through the author's biography as well as the experiences of the Prince. It concludes that, for any flaws in his reasoning, his beliefs still offer a viable solution to the complex, minute, and numerous doubts which surround any debate in our modern, data-ridden world.

The evils of the world are monstrous as well as minute: the moment you point one out, reveal it standing there, distinctly horrible, you will see its edges bleed into the circumstances surrounding it and the obvious blackness of its substance blend irrevocably among the tints of regular life. A murder in broad daylight should leave no doubt, but the obviousness of that too may seep away on closer examination. So where do we locate the boundaries of guilt? Where, so to speak, on such a blended landscape, should we build a prison's walls? The devil's crimson tail is twisted up among the chains of circumstance, the causal links of which dangle into the invisible deep, so much so that if I steal something from you, how correct is it to say that I'm the criminal, only me, and never mind the miasma of influences I grew up in? These questions animate the thoughts and anxieties of Prince Nekhlyudov, the hero of Leo Tolstoy's late novel, Resurrection. For most of the novel he cannot find an answer to them or, at least, will not accept any answer which comes too easily. The problems of nineteenthcentury Russia are both monstrous and minute, with its new and uncertain trials by jury, the idle vampirism of its gentry and the poverty of its peasants, and its notoriously paranoid and repressive regime. How can the solution be simple and clear and not shatter its delicate edges as it moves from problem to problem?

This paper will explore the notion of Truth as something simple and historically reduced to its clearest potency, as well as the qualities of this Truth and its formation both in Resurrection 
and Tolstoy's own life. To do this I will draw on several scholarly sources in addition to two of the writer's own works: Resurrection, and his spiritual autobiography, A Confession.

How did Tolstoy find his holy distillate to be able to put it in the hands of his avatar, Prince Nekhlyudov? Looking at the author's youth, it might seem less than inevitable that he would ever undertake, let alone succeed, at such a quest. When he first entered Petersburg's literary circle, for instance, and began knocking around with novelist Ivan Turgenev and the poet Afanasy Fet, he leagued himself on the side of pure rather than utilitarian art (Layton 220-21). He did not mean to fix the world with his fiction, as Nikolai Chernyshevsky did: art justified and sustained itself, unlike a tool or a rifle, which can only accept and transmit justification. The Tolstoy of the century's end would hold the opposite idea. You only have to look at the titles of some of his later stories to appreciate the completeness of his change: "How Much Land Does a Man Need?" and "Evil Allures, But God Endures," to name just two. Prince Nekhlyudov too begins his spiritual journey from the fortified precincts of deep egotism, though without the justification of being a great artist. He is a dilettante of a painter, who can no longer stand to look at his own unpromising paintings (Resurrection 15). He lives his life for himself: lazily, uselessly pursuing in idleness the gratification of "his healthy strong animal I," not his "spiritual I" (Resurrection 47). Like Tolstoy, he will finally resurrect himself and organize his life in pursuit of the latter. Drowning in questions, having paced his hotel room in Siberia half the night, Nekhlyudov will finally give up and throw open a copy of the Gospels at random. And incredibly-there it is! the solution to it all! the correct way to live, already long-known: discovered, distilled, and recorded centuries ago in five rules, which have never yet been improved upon. "But surely," the Prince thinks naturally enough, "it cannot be so simple" (Resurrection 459). The question remains: what led to this sudden epiphany which caused such a profound change for both the writer and his character in this novel?

Tolstoy in his middle life, having already written two of the strongest contenders for Greatest Novel of the Century, became suddenly and enormously depressed. He wasn't simply blue. He gave up hunting, no small thing for Tolstoy, in order to avoid finding himself alone in the woods with his rifle and the easy solution it offered (Confession 19). But these black fires scourged and cleansed him and turned him inward to religion; he came out the other side more spirit than body, enlightened and reborn, ready, as Susan Layton puts it, to "mount an anarchistic attack on the Russian state and the Orthodox Church" (222).

Tolstoy showed more mercy on his Prince Nekhlyudov than he received himself in his own crisis. The Prince never plummets to the depths and can always trust himself with a rifle, alone in the woods, but his rebirth brings its own variety of pain. His aristocrat's insularity, that of a well-fed fetus cozy in its womb, bursts apart and expels him abruptly, unannounced, the day he serves on the jury of a murder trial. One of the defendants is Katiusha Maslova, a prostitute. He had seduced her decades ago, when she had been his aunts' ward. As a juror at her trial, he plays a part in a stupid technicality-a symptom of Russia's fastidious bureaucracy in combination with its new, shaky-kneed jury trials-with the result that she is declared "not guilty of the poisoning, yet ... condemned to penal servitude" (Resurrection 88). Nekhlyudov is horrified and racked with guilt. His own resurrection begins, and his "spiritual I" rips itself free of his ego, leading him to make immediate, grand, Tolstoyan changes to his life. He gives his ample land, for one thing, to the peasants living on it (Resurrection 239).

Reborn, or resurrected, the living soul may begin to sort the questions of life into their real relations. A premonition of its simplicity seems to guide the search for Truth. Tolstoy, 
throughout his novel, sorts matters into clear oppositions, dividing them to either side of the brilliant fissure which proceeds from the correct division of the animal/spiritual $I$. The actual relations between oppositions arise. The coddled gentry stand in contrast to the prisons while, more abstractly, "falsehood lords it over truth, force over . . . justice, the base over the lofty," as Sergei A. Nikolsky puts it, defining Prince Nekhlyudov's new understanding (36). Once he comes to see these real relationships he can begin to address their causes. This sorting does not erase shades of difference but rather views them from a heavenly vantage, shrinking differences, for the sake of management, until broad similarities arise. Thus force, falsehood, and the aristocracy, composed of a million various atoms, become mountains. Now Prince Nekhlyudov and Tolstoy, and we as readers, can perceive how these mountains crush goodness and truth beneath them as they do peasants and prisoners.

Truth, for Tolstoy, has a location. It's in the Bible: written out like a prescription, which is where Prince Nekhlyudov finally finds it-or manages to see it. But before that final scene of the novel, when the Prince opens his Bible, Tolstoy actually offers him time and again that same truth. He puts it in the mouths of peasants who, as Tolstoy believed, "are closer to the truth than intellectuals" (Caws 58). Intellectuals argue and doubt, and a powerful mind can sack any ancient citadel of belief. The thinkers of Tolstoy's day found complex breaches into his own doctrine of nonresistance. Their arguments, as Maria Gelfond maintains convincingly, hold up as well as Tolstoy's own (56). Intellectually, anyway, a doubt can always be raised, but the Truth, once it is revealed, clings to the soul below the level of words and intellect. It might be better to say that it clings to the soil, the withdrawing from which, across centuries, to the idle drawing rooms and aristocratic clubs, to the tobacco-reeking debates of philosophers' papers, "is the root of the evil" (Wenzer 444). In the jury room at the prostitute Maslova's trial, one old man, a worker, refuses to debate the question of guilt and innocence, explaining, "We are not saints ourselves" (Resurrection 81). Prince Nekhlyudov meets another peasant later, an old nameless wanderer, while crossing on a ferry in Siberia. "There are many faiths," he tells the Prince, "but the spirit is one ... [The Tsar] is his own Tsar, and I am my own Tsar" (Resurrection 435-36). For Tolstoy, Truth appears not in the drawing room or even the study but turns up, like potatoes, in the soily hands of the peasants.

So what is that simple truth which, like dirty potatoes, appears more often among peasants than philosophers; the truth which Tolstoy earned by a nearly suicidal gestation, reborn into it, and which he transmits to Prince Nekhlyudov in that final scene, mentioned above; the truth which the two peasants adhere to and, though he is as yet blind and deaf, display to the Prince, having learned it not from philosophers or even the Church, but from the voice of their blood, as it were? Tolstoy puts it into five laws, drawing them from the Sermon on the Mount, as follows: "The first law was that man should not kill ... The second law was that man should not commit adultery ... The third law was that man should never bind himself by oath ... The fourth law was that man [should turn the other cheek] ... The fifth law was that man . . . should love [his enemies]" (Resurrection 460). Can the Truth, as Prince Nekhlyudov asks, really be so simple?

I mentioned above that Tolstoy's ideas cannot escape the intricate invasions of the intellect. It was not his intention to find Truth through reason which, Tolstoy writes, tends to be "sheer indulgence ... [and] there was no meaning to be found there" (Confession 66). Nonetheless, he does mount a defense against many of his critics. Against the criticism that force is occasionally expedient, he opposes the simple argument that, as no two people can 
agree on the nature of evil, to use force to counter evil is to risk harming the innocent, to risk spreading evil (Gelfond 44). For Tolstoy, Truth, in itself and in defense of itself, evinces simplicity. Only falseness or the justification of the status quo require philosophical labyrinths.

The problems of the world may be legion as well as deeply interwoven into the fabric of life and history. The answers to them-truth, that is, as Tolstoy has it-are not required to be equally monstrous. As we have seen, simplicity itself is evinced by the clear dualities which divide the world before Nekhlyudov's disabused eyes, by the modest beliefs of the peasants raking up their potatoes, and by those five rules which save and comfort the Prince in his sleepless anxiety; simplicity itself stands in opposition to the problems of the world. That which lacks simplicity is suspect; that which reeks of the smoking room, of ladies' perfumes, and not of soil, is probably wrong. And therefore I believe Tolstoy's ideas as well as Prince Nekhlyudov's, should they fail to strike a chord with the reader in their substance, can still guide us by their form. The world has grown only more complex, and we no longer require the work of intellectuals to help us destroy any argument. We only have to go online. And so we might look to this notion that simplicity guides us to Truth and feel comforted. Data are not the point; we do not need elaborate arguments. That's all as worldly and temporary as pipe smoke. Moral Truth, on the other hand, comes to us without doubts, as frank and simple-and as hardy-as, yes, a potato. 


\section{References}

Caws, Peter. "Moral Certainty in Tolstoy." Philosophy and Literature, vol. 24, no. 1, Apr. 2000, pp. 49-66.

Gelfond, Maria L. "Criticism of Leo Tolstoy's Doctrine of Nonresistance to Evil by Force in Late-Nineteenth- and Early-Twentieth-Century Russian Religious-Philosophical Thought: Three Main Arguments." Russian Studies in Philosophy, vol. 50, no. 2, 2011, pp. 38-57.

Layton, Susan. "A Hidden Polemic with Leo Tolstoy: Afanasy Fet's Lyric 'Mine Was the Madness He Wanted ..." Russian Review: An American Quarterly Devoted to Russia Past and Present, vol. 66, no. 2, Apr. 2007, pp. 220-237.

Nikolsky, Sergei A. "Meanings and Values of the Russian World Outlook in the Work of Leo Tolstoy." Russian Studies in Philosophy, vol. 50, no. 2, 2011, pp. 8-37.

Tolstoy, Leo. A Confession. Translated by Jane Kentish, Penguin Books, 2008.

Resurrection. Translated by Louise Maude, Barnes \& Noble, 2006.

Wenzer, Kenneth C. "Tolstoy's Georgist Spiritual Political Economy (1897-1910)." Pennsylvania History: A Journal of Mid-Atlantic Studies, vol. 64, no. 4, 1997, pp. 534-542. 
